\title{
Eocene Orthoptera from Green River Formation of Wyoming (USA)
}

\section{Эоценовые прямокрылые (Orthoptera) из формаџии Грин Ривер в Вайоминге (США)}

\author{
Andrej V. Gorochov ${ }^{1}$ \& Conrad C. Labandeira ${ }^{2}$ \\ А.B. Горохов, К.К. Аабандейра
}

\footnotetext{
${ }^{1}$ Zoological Institute, Russian Academy of Sciences, Universitetskaya nab. 1, St.-Petersburg 199034, Russia. E-mail: orthopt@ zin.ru

1 Зоологический институт РАН, Университетская наб. 1, Санкт-Петербург 199034, Россия.

${ }^{2}$ National Museum of Natural History, Smithsonian Institution, Washington DC 20013-7012, USA. E-mail: labandec@si.edu
}

KEY WORDS: Orthoptera, Eocene, Green River Formation, Wyoming, USA, review, new taxa.

КЛЮЧЕВЫЕ СЛОВА: прямокрылые, Orthoptera, эоцен, формация Грин Ривер, Вайоминг, США, обзор, новые таксоны.

ABSTRACT. A review of fossil Orthoptera from Green River Formation of Wyoming (Middle Eocene) is given. Pterotriamescaptor? americanus sp.n., Eomogoplistes longipennis gen. et sp.n., Pteromogoplistes grandis gen. et sp.n., Eogryllus unicolor gen. et sp.n., E.? elongatus sp.n., Eozacla arachnomorpha gen. et sp.n., E. problematica sp.n., Eotrella mira gen. et sp.n., Tettoraptor maculatus gen. et sp.n., Eotettix unicornis gen. et sp.n., and Eoerianthus eocaenicus gen. et sp.n. are described. Two species, Pteromogoplistes smithii (Scudder, 1890), comb.n. and Pronemobius tertiarius (Scudder, 1878) are restudied on the base of new material possibly belonging to these species; systematic position of them and of Eoerianthus? multispinosus (Scudder, 1890), comb.n. is clarified. Some general remarks on the Orthoptera fauna of Green River Formation are made.

РЕЗЮМЕ. Дан обзор ископаемых прямокрылых из формации Грин Ривер штата Вайоминг (средний эоцен). Описаны Pterotriamescaptor? americanus sp.n., Eomogoplistes longipennis gen. et sp.n., Pteromogoplistes grandis gen. et sp.n., Eogryllus unicolor gen. et sp.n., E.? elongatus sp.n., Eozacla arachnomorpha gen. et sp.n., E. problematica sp.n., Eotrella mira gen. et sp.n., Tettoraptor maculatus gen. et sp.n., Eotettix unicornis gen. et sp.n. и Eoerianthus eocaenicus gen. et sp.n. Виды Pteromogoplistes smithii (Scudder, 1890), comb.n. и Pronemobius tertiarius (Scudder, 1878) переизучены на основе нового материала, возможно, относящегося к этим видам; систематическое положение их и Eoerianthus? multispinosus (Scudder, 1890), comb.n. уточнено. Высказаны некоторые общие соображения о фауне прямокрылых формации Грин Ривер.

The collection of the National Museum of Natural History in Washington (USNM) contains numerous imprints of fossil Orthoptera collected mainly by David Kohls, an outstanding collector of fossils in the Green
River Formation of Wyoming. This formation situated on the territory of 3 states of USA (Utah, Colorado and Wyoming) in the basin of Green River, a tributary of Colorado River. Age of this formation is usually treated as Middle Eocene; the recent investigators consider that these depositions might be formed during approximately 6 millions years inside the first half of Eocene (from Ypresian stage to Lutetian stage [Smith et al., 2008]).

The imprints of fossil Orthoptera are usually presented by the indistinct spots having only outlines of insect bodies often with the traces of pigmentation. Sometimes, the outlines are distinct, and the pigmentation is rather well preserved. Such "theatre of shadows" allows us to give mainly approximate determinations. There are also several body imprints with the distinct wing venation and some other structures important for taxonomy of Orthoptera. It is surprising, but this rich material almost doesn't contain any isolated wings!

The above-mentioned peculiarity of these imprints may explain the absence of any attempts of work with this material on Orthoptera excepting 2 publications by S.H. Scudder [1878, 1890]. This author indicated from Green River Formation of Wyoming 3 species of Gryllidae and 1 species of "Acridii" which are discussed here in the paragraphs about Pteromogoplistes gen.n., Pronemobius Scudder, 1890 and Eoerianthus gen.n.

\section{Suborder Ensifera \\ Infraorder Gryllidea \\ Superfamily Grylloidea \\ Family Gryllotalpidae \\ Subfamily Gryllotalpinae}

This subfamily includes 3-4 recent and 1 fossil genera characterized by the presence of 3 or 4 strong digging teeth on distal edge of fore tibia ( 2 teeth, articulated with the tibia, originate from the apical tibial spurs; 1 or 2 additional teeth, fused with the tibia, are simple tibial processes) and a very strong process on proximal part of fore femur. Majority of recent Gryllotalpidae belongs to this subfamily known since Eocene only. It is useful to note that all dependably known 
Eocene Gryllotalpinae had 3 tibial digging teeth. The same number of these teeth is presented also in 1 recent relict genus from New Zealand (Triamescaptor Tindale, 1928). All other recent Gryllotalpinae have 4 tibial digging teeth, and after Early Oligocene, all fossil Gryllotalpinae with known fore legs are characterized by 4 teeth on their tibia. Moreover, the youngest larves of the most usual recent genus of Gryllotalpinae (Gryllotalpa Latreille, 1802) are provided with only 3 teeth on fore tibiae.

These facts allowed Gorochov [1992, 1995a] to propose the hypothesis about main directions of evolution in Gryllotalpidae. The general ancestor of Gryllotalpinae and Scapteriscinae had only 2 articulated digging teeth on fore tibia (as in recent Scapteriscinae), but femur and trochanter of their fore legs had not any strong processes. Intensification of digging mode of life in mole crickets led to independent strengthening of digging legs in Scapteriscinae and Gryllotalpinae: the first subfamily preserved the presence of only 2 articulated digging tibial teeth and acquired a strong process on the fore trochanter; the second subfamily acquired third digging tibial tooth (tibial process) and a strong process on the fore femur. Gryllotalpinae with the latter condition of fore tibia were distributed in Eocene and maybe in Early Oligocene. Triamescaptor from New Zealand is a possible recent relict of this stage of Gryllotalpinae evolution. After Early Oligocene, such primitive representatives of Gryllotalpinae were replaced by the younger group of Gryllotalpinae having 4 digging teeth of fore tibia.

This hypothesis was supported by a few new finds of fossil Gryllotalpidae. They are the Early Cretaceous genera from Brazil [Martins-Neto, 1995, 1997] and France [Perrichot et al, 2002] having only 2 digging tibial teeth and lacking processes on the femur or trochanter of fore legs (such structure of these legs, similar to that in the hypothetical ancestor of both subfamilies, allows Gorochov [2010] to put these genera in the paraphyletic Early Cretaceous subfamily Marchandiinae), and the imprint of Gryllotalpinae from Eocene of USA considered below.

\section{Genus Pterotriamescaptor Gorochov, 1992}

Type species: Gryllotalpa prima Cockerell, 1921 (England; Early Oligocene).

DIAGNOSIS. Pterotriamescaptor distinguished from all other genera of Gryllotalpinae with known wing venation by very wide area between $1 \mathrm{~A}$ and $2 \mathrm{~A}$ in proximal part of male tegmina (for comparison see Gorochov [1992: Table of figs 1]; terminology of veins is given under Sharov [1968] and Gorochov [1995a]). Possibly this genus additionally characterized by fore legs with 3 digging tibial teeth (Fig. 1), as in Eocene representatives of Gryllotalpinae and in recent Triamescaptor from New Zealand; from latter genus, Pterotriamescaptor distinguished by well developed wings, but its differences from all studied Eocene representatives (their wing venation unclear) unknown, and belonging of these Eocene species to Pterotriamescaptor also possible.

INCLUDED SPECIES. Type species; possibly Gryllotalpa tridactylina Secretan, 1975 (Italy; Middle Eocene) and $P . ?$ americanus sp.n.

NOTE. It is necessary to note that $P$. primus was described for only male tegmen [Cockerell, 1921] (there are some additional undescribed imprints of this species from the same locality, but fore tibiae in these imprints are not preserved), and P.? tridactylinus is known for a single imprint of almost complete body with 3 teeth on fore tibia and indistinct venation of well developed wings [Secretan, 1975; Capra, 1977]. These imprints don't allow one to compare them in relation to the structure of fore legs and tegminal venation.
These species may belong to the same genus as well as to 2 different genera, and their relationship may be examined by new imprints of these species. However the both species cannot belong to any recent genus of Gryllotalpinae, as all genera of recent Gryllotalpinae (excepting apterous Triamescaptor) have the following synapomorphies absent in the above-mentioned fossil species: fore tibia is provided with 4 digging teeth (excepting youngest larves); the proximal part of male tegmina has much narrower area between 1A and 2A which is not wider than area between stridulatory vein $(\mathrm{CuP})$ and $1 \mathrm{~A}$. Moreover, difference between $P$. primus and P.? tridactylinus in age is not very big. This possible relationship was rejected by Perrichot et al [2002] illogically suggesting to include the Eocene species with 3 digging teeth on fore tibia in the genus Gryllotalpa, one of recent genera of Gryllotalpini with 4 such teeth. So, these authors suggest us to use the undoubtedly erroneous decision instead the hypothetical decision which has not contradictory facts now and may be supported or refuted by new finds in future.

\section{Pterotriamescaptor? americanus Gorochov, sp.n.} Fig. 1.

MATERIAL. Holotype: imprint of fore part of body with one of fore legs and traces of imaginal wings (sex unknown), N. 51944 [USNM (DS 98) 41619].

DESCRIPTION. Size of body comparatively small for subfamily. Pronotum rather short (its width bigger than its length). Fore tibia with 3 digging teeth; third of these teeth without traces of articulation with tibia (tibial process), moderately short (almost twice shorter than other tibial teeth), and almost angularly lobe-like in shape. Fore basitarsus probably with long tooth visible in imprint between longest tibial teeth and equal to these teeth in length.

MEASUREMENTS (in $\mathrm{mm}$ ). Length of pronotum 5; width of pronotum 5.6; length of imprint 14.7; hypothetical length of body (without antennae, palpi, legs, wings and cerci) 18-20.

COMPARISON. The new species is similar to P.? tridactylinus in the structure of fore tibiae, but it differs from the latter species in the distinctly shorter third tooth of fore tibia. From P. primus, the new species is distinguished by the somewhat shorter pronotum (length and width of pronotum of $P$. primus from Isle of Wight are practically equal).

\section{Family Mogoplistidae \\ Subfamily Mogoplistinae$$
\text { Tribe Mogoplistini }
$$

This tribe is most primitive among Mogoplistinae and consists of 6-7 recent and 2 new fossil genera characterized by the wide clypeus (much wider than antennal scape), the narrow tarsi (lacking widened pulvillae), and the hagloid (not grylloid) type of male genitalia [Gorochov, 1984, 1995a]. It is interesting to note that all recent Mogoplistidae are lacking hind wings, and their females are completely apterous. However, in the both Eocene genera described below, all wings are developed.

\section{Genus Eomogoplistes Gorochov, gen.n.}

Type species: E. longipennis sp.n.

DIAGNOSIS. Size of body small for Mogoplistini. Rostrum between antennae approximately 3.5 times as wide as scape. Pronotum almost 1.6 times as wide as head; its fore part distinctly narrowing; its lateral sides strongly convex. Male tegmina moderately shortened (not shorter than pronotum) and with almost truncated apex; hind wings well developed, long (Fig. 2). 
INCLUDED SPECIES. Type species only.

COMPARISON. The new genus differs from all previously described genera of Mogoplistidae in the presence of hind wings.

\section{Eomogoplistes longipennis Gorochov, sp.n.}

\section{Fig. 2.}

MATERIAL. Holotype: imprint of male body with indistinct venation and without right hind wing and distal parts of legs, $\mathrm{N}$ 75704 (IKAO 127) [USNM 40193 (Anvil Points)]. Paratype: imprint of body with less distinct outlines than in holotype (sex unknown), N. 25299 [USNM (AP LS 95) 41088].

DESCRIPTION. Coloration of all preserved parts of body darkish, but with light transverse stripe along hind edge of tegmina. Hind femora somewhat longer than abdomen.
Abdominal anal plate between cercal bases wide and weakly convex.

MEASUREMENTS (in mm). Length of body (without antennae, palpi, legs, wings and cerci) 3.7 ; length of body with visible parts of wings 6.5 ; length of pronotum 0.8 ; width of pronotum 1.2; length of tegmen 0.9 ; length of hind femur 1.8; length of visible part of hind tibia 1.

\section{Genus Pteromogoplistes Gorochov, gen.n.}

Type species: $P$. grandis $\mathbf{s p .} \mathbf{n}$.

DIAGNOSIS. Size of body rather large for Mogoplistini. Rostrum between antennae approximately 3 times as wide as scape. Pronotum almost 1.3 times as wide as head, very slightly narrowing to head; its lateral sides almost straight.
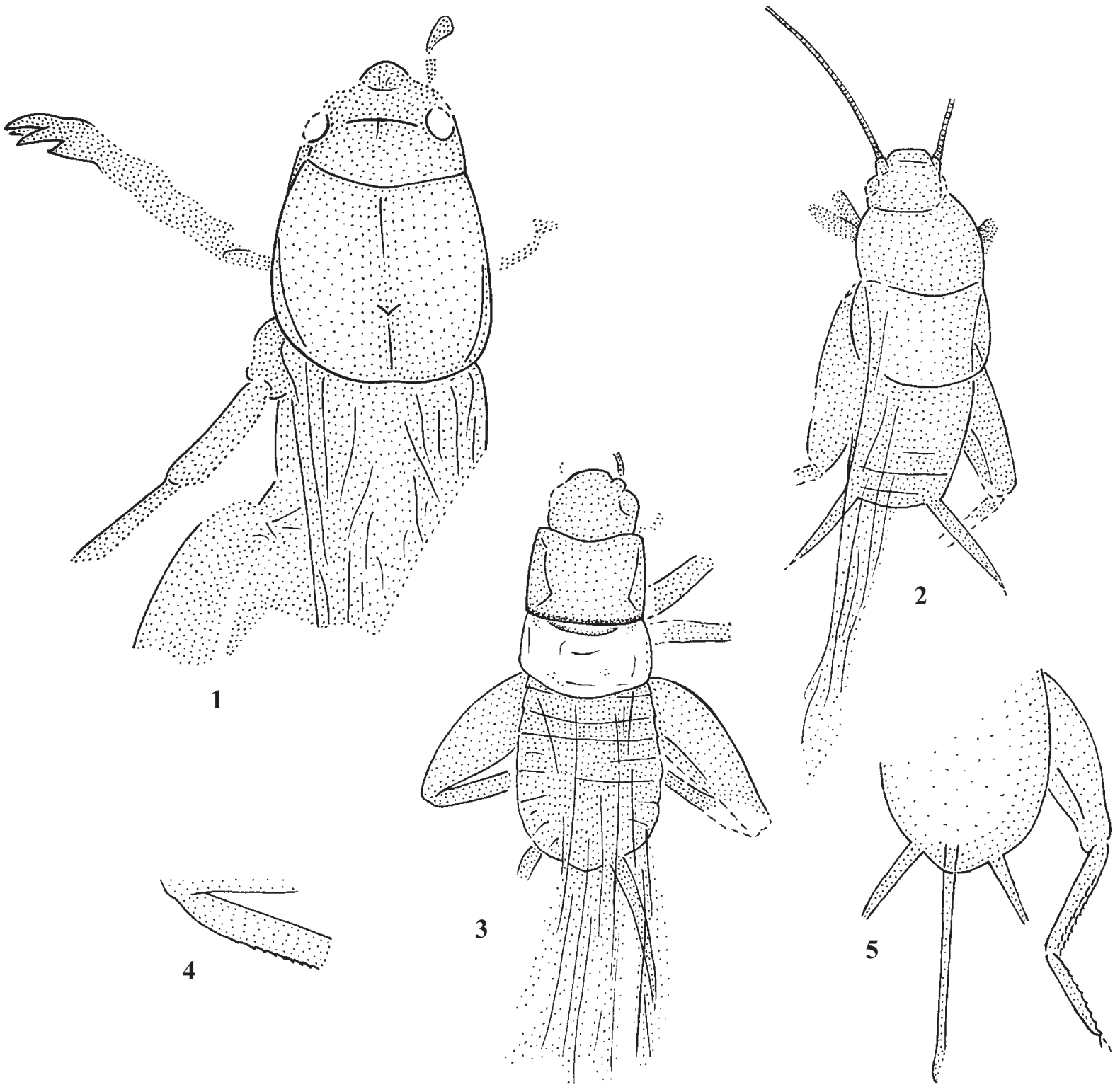

Figs 1-5. Gryllotalpidae (1) and Mogoplistidae (2-5): 1 - Pterotriamescaptor? americanus sp.n. (holotype No. 51944); 2 Eomogoplistes longipennis sp.n. (holotype No. 75704, male); 3-5 - Pteromogoplistes grandis sp.n. (3-4 - holotype No. 18608, male; 5 - paratype No. 27111 \& 25254, female); $1-3$ - body or its part from above; 4 - proximal part of hind tibia from side; 5 - hind part of body from below.

Рис. 1-5. Gryllotalpidae (1) и Mogoplistidae (2-5): 1 - Pterotriamescaptor? americanus sp.n. (голотип № N. 51944); 2 - Eomogoplistes longipennis sp.n. (голотип № 75704, самец); 3-5 — Pteromogoplistes grandis sp.n. (3-4 — голотип № 18608, самец; 5 — паратип № 27111 \& 25254, самка); 1-3 - тело и его части, сверху; 4 - проксимальная часть задней голени, сбоку; 5 - задняя часть тела, снизу. 
Male tegmina strongly shortened (distinctly shorter than pronotum) and with distinctly convex apex; hind wings well developed, long (Fig. 3). Hind tibiae with only small denticles as in all recent Mogoplistidae (Fig. 4); hind basitarsi with distinct denticles on upper surface (Fig. 5).

INCLUDED SPECIES. Type species; possibly Pronemobius smithii Scudder, 1890 (USA, Wyoming; Middle Eocene).

COMPARISON. The new genus differs from Eomogoplistes sp.n. in the larger body, shorter male tegmina, and narrower head rostrum and pronotum. From all other genera of Mogoplistidae, it is distinguished by the presence of hind wings.

\section{Pteromogoplistes grandis Gorochov, sp.n.} Figs 3-5.

MATERIAL. Holotype: imprint of male body with indistinct venation and without distal parts of fore and middle legs, N. 18608 [USNM (AP KS 98) 41616]. Paratypes: imprints of bodies of males and females less complete or with less distinct outlines than in holotype; 5 males: N. 27267 [USNM (AP LS 95) 41088], N. 53162 [USNM Site 4 (DS 99) K 41088], N. 115148 [USNM 40910 (Anvi Points - Pribyl)], N. 87113 [USNM 40193 (Anvil Points - Kohls collected 1991)], N. 78709 [USNM 41140 (Anvil Points)]; 3 females: N. 51620 [USNM Site 4 (DS 98) 41617], N. 28374 [USNM (LS 98) 41235], N. $27111 \& 25254$ [USNM (AP LS 95) 41088].

DESCRIPTION. Size of body very large. Coloration darkish with light tegmina. Hind femora approximately as long as abdomen; hind tibiae distinctly shorter than hind femora; hind basitarsi slightly shorter than hind tibiae. Abdominal anal plate between cercal bases in male and female similar, wide and strongly convex; ovipositor long and thin.

MEASUREMENTS (in mm). Length of body (without antennae, palpi, legs, wings and cerci) $9.5-11$; length of body with visible parts of wings 16 ; length of pronotum 2-2.2; width of pronotum 2.8-3; length of tegmen 1.7-1.9; length of hind femur 4.6-5; length of hind tibia 3.3; length of ovipositor 6-7.

COMPARISON. The difference between 2 species of this genus is listed below.

\section{Pteromogoplistes ?smithii (Scudder, 1890), comb.n.}

Pronemobius smithii Scudder, 1890.

MATERIAL. Imprints of almost complete bodies of males and females; 28 specimens: N. 86921 [USNM 40189 (Old Mountain)], N 105299-AB [USNM 40911 (Mahaffey Trail), N. 85505 [USNM (OM 95) 41086], N. 26047-AB [USNM (AP LS 95) 41075], N 77958 [USNM 40193 (Anvil Points)], N. 75784 [USNM 40193 (Anvil Points)], N. 57647 [USNM 41142, Denson 2001, Site \# 4], N. 27145 [USNM (AP LS 95) 41088], N. 25703-AB [USNM (AP LS 95) 41088], N. 51901 [USNM (DS 98) 41619], N. 58079 [USNM 41142, Denson 2001, Site \# 3], N. 56129-AB [USNM 41142 Denson 2001, Site \# 3], N. 27853-AB [USNM (AP LS 96) 41222], N 55365 [USNM 41142, Denson 2001, Site \# 3], N. 26331 [USNM (AP LS 95) 41088], N. 50460 [USNM (DS 96) 41220], N. 52603-AB [USNM (DS 99) K, 41679], N. 28528 [USNM (LS 99) K, 41678], N. 105343 [USNM 40911 (Mahaffey Trail)], N. 25384 [USNM (AP LS 95) 41088], N. 27857 [USNM (AP LS 96) 41222], N. 6 [USNM 40193 (Anvil Points)], N. 54493 \& 54494 [USNM site \# 4 (DS 00) 41822], N. 105709 [USNM (MT 98) P, 41234], N. 26315 [USNM (AP LS 95) 41088], N. 29086 [USNM (LS 99) K, 41678], N. 138565 [USNM (LW 98) 41236], N. 54907 [USNM site \# 4 (DS 00) 41822]

NOTE. The type material on this species was not restudied as it was not found in USNM, one of possible repositories of Scudder's paleontological types from Green River Formation. The original description of this species [Scudder, 1890] is in accordance to the above-listed specimens (it is necessary to note that belonging of this Scudder's species to Mogoplistidae is supported also by the absence of distinct hairs on its legs and of long spines on its hind tibiae). This species is very similar to previous one, but it is well distinguished from $P$. grandis sp.n. by the distinctly smaller size (see measurements below).
MEASUREMENTS (in mm). Length of body (without antennae, palpi, legs, wings and cerci) 6-7; length of body with wings $10-12$; length of pronotum $1.4-1.6$; width of pronotum 1.9-2.2; length of tegmen 1.1-1.3; length of hind femur 3.2-3.8; length of hind tibia 2.2-2.6; length of ovipositor not less than 3.5 .

\section{Pteromogoplistes sp.}

MATERIAL. Imprints of incomplete bodies of males and females; 7 specimens: N. 27663 [USNM (AP LS 95) 41088], N. $27638 \& 25945$ [USNM (AP LS 95) 41075], N. 57348-AB [USNM 41142, Denson 2001, Site \# 4], N. 30469 [USNM (LS 97) 41225], N. 55394 [USNM 41142, Denson 2001, Site \# 3], N. 26168-AB [USNM (AP LS 95) 41088], N. 52643 [USNM site \# 1 (DS 99) K, 41679].

NOTE. These specimens have body size intermediate between those of $P$. grandis and $P$. ? smithii. They may belong to small or large forms of these species as well as to a third species of this genus (see measurements below).

MEASUREMENTS (in mm). Length of body (without antennae, palpi, legs, wings and cerci) 8-9; length of pronotum 1.7-1.9 width of pronotum 2.4-2.6; length of tegmen 1.4-1.6; length of hind femur 4.2-4.4; length of hind tibia 2.9-3.1; length of ovipositor not less than 4 .

\section{Mogoplistidae incertae sedis}

MATERIAL. Imprints of bodies or their fragments with rather indistinct outlines; about 50 specimens.

\section{Family Gryllidae \\ Subfamily Gryllinae \\ Tribe Gryllini}

The tribe includes about 100 recent and 2 fossil genera, one of which is described here as new for science. This tribe is distinguished from 2 other tribes of Gryllinae (Sclerogryllini and Eurygryllodini) by the presence of long and usually articulated spines on the upper surface of hind tibiae as well as absence of small denticles on the proximal part of this tibial surface (in Sclerogryllini, the upper surface of hind tibiae is secondarily with only denticles; in Eurygryllodini, it is in possible primitive condition: with long distal spines and small proximal denticles). It is necessary to note that the subfamily Gryllinae is sometimes divided into more numerous tribes or even 2 subfamilies (for example Gryllinae and Brachytrupinae [Otte, 1994]) which are close related to each other and may be considered only 2 subtribes of the tribe Gryllini [Gorochov, 1983, 1995a].

\section{Genus Eogryllus Gorochov, gen.n.}

Type species: E. unicolor $\mathbf{s p .} \mathbf{n}$.

DIAGNOSIS. Size small for this subfamily. Shape of body typical for Gryllini: head large and almost globular; pronotum with almost parallel lateral sides; legs rather short and strong (Figs 7-8). Male tegmina with well developed stridulatory apparatus containing 3-5 oblique veins ( 2 longest of them S-shaped), slightly curved chords, more or less oval mirror having 1 dividing crossvein, rather long apical area probably extending to abdominal apex, and parallel longitudinal veins in lateral area, but without special transverse cell completely isolating mirror from apical area (Figs $6,9)$. Hind wings long (much longer than tegmina). Hind legs (Fig. 7) with thick femora; hind tibiae approximately 1.5 times shorter than hind femora. Coloration of head, pronotum, and legs uniformly darkish (Figs 7-8); wings light with some weakly darkened parts on tegmina (Figs 6, 9).

INCLUDED SPECIES. Type species and possibly E. elongatus sp.n. 
COMPARISON. This new genus is a rather formal taxon, as the recent genera of Gryllini are separated from each other on the base of almost only male genital characters. It is described for only Paleogene representatives of this tribe having the structure of body typical for recent Gryllini: small size, parallel longitudinal veins in lateral area of tegmina, almost rounded mirror, short hind tibiae, and more or less uniform coloration (in Eocene genus Pronemobius, legs are spotted or partly lineated, and hind tibiae are approximately 1.3 times shorter than hind femora; Figs 10-12).

\section{Eogryllus unicolor Gorochov, sp.n. Figs 6-7.}

MATERIAL. Holotype: imprint of male body with distinct tegminal venation and incomplete fore and middle legs, N. 77904 [USNM 40193 (Anvil Points)]. Paratypes: imprints of bodies with indistinct both venation and structure of abdominal apex (sex unknown); 16 specimens: N. 138758-AB [USNM (LW 98) 41236], N 75751 \& 75752 [USNM 40193 (Anvil Points)], N. 51117-AB [USNM (DS 97) 41223], N. IKAO751-429 [USNM 40193 (Anvil Points)], N. 57653 [USNM 41142, Denson 2001, Site \# 4], N. 50479 [USNM (DS 96) 41220], N. 55248-AB [USNM (2001) (Denson Site 4) 41142], N. 57715 [USNM 41142, Denson 2001, Site \# 4], N. 57394 [USNM 41142, Denson 2001, Site \# 4], N. 57246 [USNM 41142, Denson 2001, Site \# 4], N. 54429 [USNM site \# 4 (DS 00) 41822], N. 115199 [USNM 40910 (Anvil Points Pribyl)], N. 25940-AB [USNM (AP LS 95) 41075], N. 27630 [USNM (AP LS 95) 41088], N. 27018-AC [USNM (AP LS 95) 41075], N. 50483 [USNM (DS 96) 41220].

DESCRIPTION. Male tegmina with stridulatory vein somewhat obliquely situated, 3 oblique veins, diagonal vein distinctly shorter than mirror, comparatively short chords and hind part of mirror, and not oblique longitudinal veins in apical area; coloration of tegmina light with slight darkenings along $\mathrm{R}$ and between chords. Hind tibiae with not very long spines and spurs (longest spur not longer than half of hind basitarsus).

MEASUREMENTS (in mm). Length of body 8.5-10; length of pronotum 1.3-1.6; length of tegmen $6-6.5$; length of hind femur 5-5.5; length of hind tibia 3.5-3.8

\section{Eogryllus? elongatus Gorochov, sp.n.} Figs 8-9.

MATERIAL. Holotype: imprint of male body without abdomen, hind wings, and hind legs, but with distinct tegminal venation and incomplete fore legs, N. 78333 [USNM 40193 (Anvil Points)] Paratypes: imprints of bodies with indistinct both venation and structure of abdominal apex (sex unknown); 6 specimens: N. 52512 \& 52609 [USNM site 1 (DS 99) K, 41679], N. 77942 \& IKAO753-421 [USNM 40193 (Anvil Points)], N. 105080-AB [USNM (MT 95) 41087], N. 86890 [USNM 40189 (Old Mountain)], N. 86891-AB [USNM 40189 (Old Mountain)], N. 30094-AB [USNM (LS 97) 41225].

DESCRIPTION. Male tegmina with stridulatory vein transversally situated, 4 or 5 oblique veins, diagonal vein not shorter than mirror, comparatively long chords and hind part of mirror, and oblique proximal parts of longitudinal veins in apical area; coloration of tegmina light with slight darkenings along $\mathrm{R}$, on mirror, on basal and apical areas, between chords and around diagonal vein. Legs more or less similar to $E$. unicolor sp.n., but slightly longer.

MEASUREMENTS (in mm). Length of body 11-12; length of pronotum 1.5-1.8; length of tegmen 7-7.5; length of hind femur 6-6.5; length of hind tibia 4-4.2.

COMPARISON. The new species well differs from $E$. unicolor sp.n. in the above-mentioned characters of tegminal venation and somewhat longer tegmina and legs. Belonging of the new species to this genus is questionable, as venation of its tegminal lateral area is unknown.
Genus Pronemobius Scudder, 1890

Type species: Nemobius tertiarius Scudder, 1878 (USA, Wyoming; Middle Eocene).

DIAGNOSIS. This genus similar to Eogryllus gen.n. in size and structure of body (tegminal venation indistinct), but distinguished from it by longer hind tibia (they approximately 1.3 times shorter than hind femora) and characteristic coloration of legs: fore and middle legs darkened with distinct and more or less oval light spots (Figs 11, 12); hind femora with numerous distinct oblique stripes and dark longitudinal median spot on outer surface (Fig. 10).

INCLUDED SPECIES. Type species and $P$. ornatipes Cockerell, 1921 (USA, Colorado; Eocene).

NOTE. This genus is also a rather formal taxon. However the above-mentioned differences in coloration and structure of hind legs of Eogryllus gen.n. and Pronemobius are usually characteristic of different genera in the recent Gryllini.

\section{Pronemobius ?tertiarius (Scudder, 1878)}

Figs 10-12.

Nemobius tertiarius Scudder, 1878.

MATERIAL. Imprints of incomplete bodies of males and females with indistinct venation; 18 specimens: N. 105730-AB [USNM (MT 98) P, 41234], N. IKAO739-499 [USNM 40193 (Anvil Points)], N. 138373 [USNM (LW 98) 41236], N. 536 A [USNM (AP KS 95) 41089], N. 52531 [USNM (DS 99) K, 41679], N. 139209 [USNM (LW 98) K, 41236], N. 55178-AB [USNM (year 2001) (Denson Site 4) 41142], N. 138766-AB [USNM (LW 98) 41236], N. 86906-AB [USNM 40189 (Old Mountain)], N. 58141-AB [USNM 41142, Denson 2001, Site \# 3], N. 26208 [USNM (AP LS 95) 41088], N. 25538-B [USNM (AP LS 95) 41088], N. IKAO750-525 [USNM 40193 (Anvil Points)], N. 77913-IKAO744 [USNM 40193 (Anvil Points)], N. 25717 [USNM (AP LS 95) 41088], N. 27628-AB [USNM (AP LS 95) 41075], N. 147700-AB [USNM (SAV 98) 41237], N. 28823-AB [USNM (LS 99) K, 41678].

NOTE. The type material on this species was not restudied (see Note for Pteromogoplistes ?smithii). Its descriptions [Scudder, 1878, 1890] is almost in accordance to the abovelisted specimens, but it is necessary to note that Scudder's indication of the absence of hind tibial spines in this species is probably a mistake, as in the picture of hind tibia of a syntype [Scudder, 1890: Pl. 6, Fig. 23], there are a few small dark spots which are the places of articulation of these tibiae with their spines (among the above-listed specimens, there are imprints of hind tibiae having distinct or almost indistinct spines, but all such imprints are with darkenings at the places of articulation with spines). All these specimens are with long hind wings. Differences between $P$. ?tertiarius and $P$. ornatipes are unclear; these species are very similar in the size, coloration and shape of hind legs, but other structures of the latter species are indistinct (its holotype deposited in USNM was restudied by Gorochov).

MEASUREMENTS (in mm). Length of body 9.5-11; length of pronotum 1.4-1.7; length of tegmen $6-7$; length of hind femur 5.5-6.5; length of hind tibia 4.5-4.8; length of ovipositor 7-7.5 [Scudder (1890) indicated that length of ovipositor in this species is $3.5 \mathrm{~mm}$, but the imprint studied by him has probably only proximal part of ovipositor].

\section{Pronemobius sp.}

MATERIAL. Imprints of bodies of males and females with indistinct venation and only proximal part of ovipositor; 10 specimens: N. $75727 \& 75744$ [USNM 40193 (Anvil Points)], N. 75125 [USNM 40193 (Anvil Points)], N. 87684 [USNM (OM 96) 41221], N. 56345-AB [USNM 41142, Denson 2001, Site \# 4], N. 26937 [USNM (AP LS 95) 41088], N. 77911 [USNM 40193 (Anvil Points)], N. 77912 [USNM 40193 (Anvil Points)], N. 75786 [USNM 
40193 (Anvil Points)], N. 136052 [USNM (Parachute Creek) 41139], N. 105006 [USNM 40189 (Old Mountain)]

NOTE. These specimens are very similar to $P$. ?tertiarius in the shape of body parts and coloration, but somewhat smaller (see Measurements). Their tegmina are almost not preserved. These imprints may belong to third species of this genus or to $P$. ?tertiarius (if the latter species has big variability in body size).

MEASUREMENTS (in mm). Length of body 7-8; length of pronotum $0.9-1.2$; length of hind femur 4.1-4.7; length of hind tibiae 2.8-3.2; length of visible part of ovipositor 3-4.

\section{Gryllinae incertae sedis}

MATERIAL. Imprints of bodies or legs with more or less indistinct outlines and coloration (sex unknown); 22 specimens: $\mathrm{N}$. 95759 [USNM 40190 (Paleoburn)], N. 56180 \& 56190 [USNM 41142, Denson 2001, Site \# 5], 26445-AB [USNM (AP LS 95) 41088], N. 57562 [USNM 41142, Denson 2001, Site \# 4], N. 52966 [USNM Site \# 1 (DS 99) K, 41679], N. 77918 [USNM 40193 (Anvil Points)], N. 86895 [USNM 40189 (Old Mountain)], N. 86896 [USNM 40189 (Old Mountain)], N. 86905 [USNM 40189 (Old Mountain)], N. 86907 [USNM 40189 (Old Mountain)], N. 86920
[USNM 40189 (Old Mountain)], N. 86925 [USNM 40189 (Old Mountain)] \& 25627 [USNM (AP LS 95) 41088], N. 53017-AB [USNM (DS 99) K, 41679], N. 466 [USNM 40193 (Anvil Points)], N. 29340 [USNM 41235 (LS 98) P], N. 50485-AB [USNM (DS 96) 41220], N. 50461 [USNM (DS 96) 41220], N. 17 [USNM (AP KS 95) 41089], N. 50482-AB [USNM (DS 96) 41220], N. $28613 \&$ 28612 [USNM (LS 99) K, 41678], N. 31104-AB [USNM (LS 99) K, 41678], N. 87681 [USNM (OM 96) 41221].

\section{Subfamily Phalangopsinae}

The tribal position of 2 possible genera of Phalangopsinae, which are described below, is unclear. But they undoubtedly belong to different tribes. Moreover, it is impossible to exclude that the second genus may belong to another or a new subfamily. Discussions on systematic position of these genera are given after their descriptions.

Genus Eozacla Gorochov, gen.n.

Type species: E. arachnomorpha sp.n.

DIAGNOSIS. Medium-sized crickets with long legs and hind wings. Lengths of tibia and femur of each leg almost

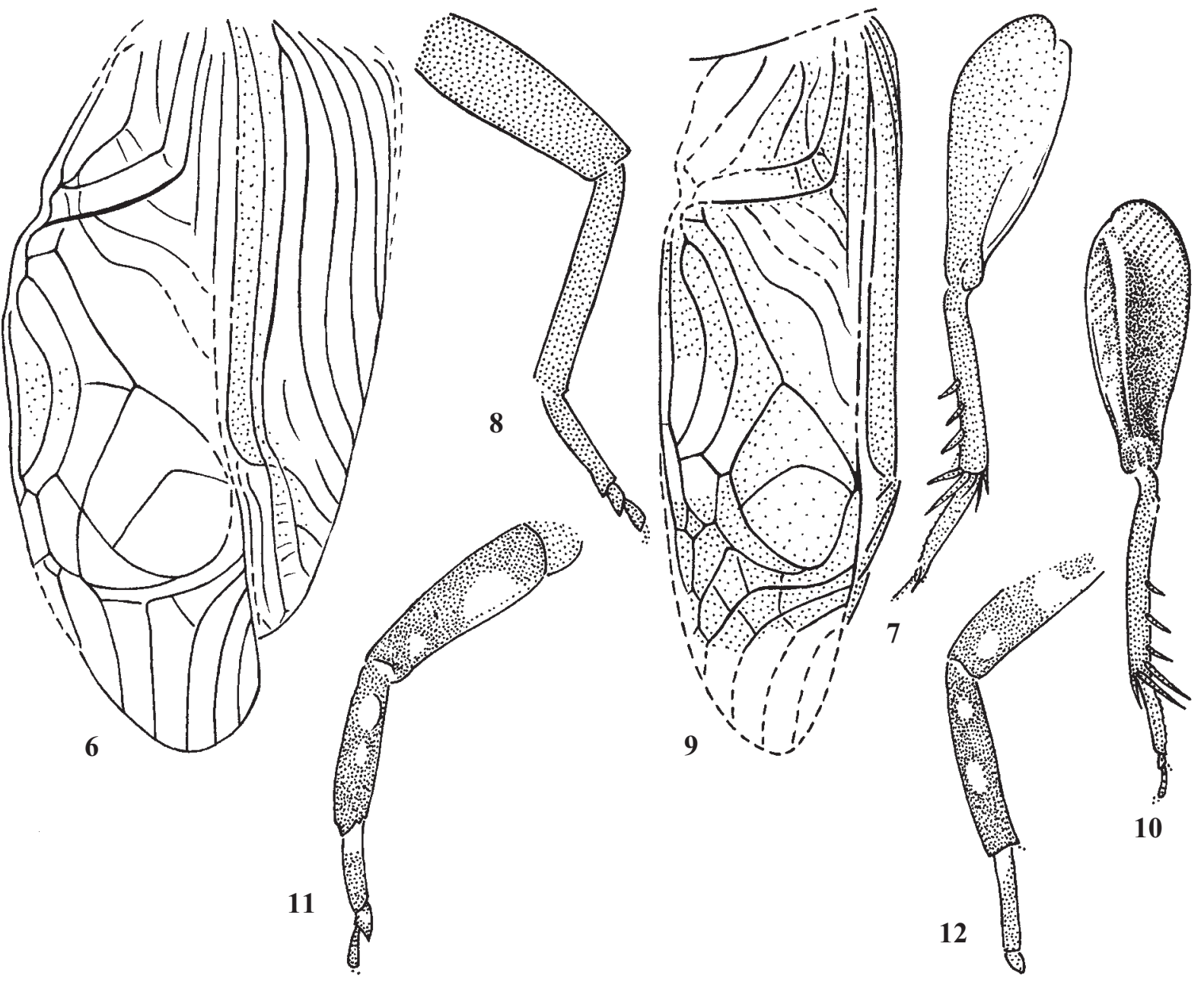

Figs 6-12. Gryllidae: 6-7 - Eogryllus unicolor sp.n. (holotype No. 77904, male); 8-9 - E.? elongatus sp.n. (holotype No. 78333, male); 10-12 - Pronemobius ?tertiarius $(10$ - No. 105730; 11-12 - No. 55178); 6 - right tegmen; 9 - its dorsal part; 7,10 — hind leg (7 - from inner; 10 - from outer sides); 8, 12 - middle leg; 11 - fore leg; 8, 11-12 - from side.

Рис. 6-12. Gryllidae: 6-7 - Eogryllus unicolor sp.n. (голотип № 77904, самец); 8-9-E.? elongatus sp.n. (голотип № 78333, самец); 10-12 - Pronemobius ?tertiarius (10 - № 105730; 11-12 - № 55178); 6 - правое надкрылье; 9 - его дорсальная часть; 7,10 - задняя нога (7 - с внутренней, 10 - с наружной стороны); 8, 12 - средняя нога, 11- передняя нога; 8, 11-12 - сбоку. 
equal, or tibia only slightly shorter; fore and middle legs with spotted tibiae and narrow tarsi lacking widened pulvillae, but provided with long basitarsus (Figs 13-14); hind femur rather narrow; hind tibia with rather short articulated spines and small denticles between them (Fig. 13). Ovipositor more or less long and narrow; its apex typical of primitive Phalangopsinae (Fig. 15).

INCLUDED SPECIES. Type species and E. problematica sp.n.

COMPARISON. This genus is a rather formal taxon, as the recent primitive genera of Phalangopsinae are separated from each other mainly on the base of genital characters of male. It is described for only Paleogene representatives of this subfamily having the following primitive characters: legs and hind wings long, ovipositor simple (its apical part is gradually narrowed to the acute apex, subapical part of dorsal valves without large ventral lobe, and narrowing of these valves before their subapical part weak and more or less sloping). There are also 2 Paleogene genera probably related to Phalangopsinae: Late Eocene Electrogryllus Gorochov, 1992 (Phaloriinae) and Early Oligocene Eneopterotrypus Zeuner, 1937 (Pteroplistinae). The new genus differs from Electrogryllus in the second tarsal segment not widened. From Eneopterotrypus (described for only male tegmen unknown in Eozacla gen.n.), it may be distinguished by the clearly longer legs; because all the other known species of Pteroplistinae have the rather short legs.

\section{Eozacla arachnomorpha Gorochov, sp.n.} Fig. 13.

MATERIAL. Holotype: incomplete imprint of body of male without tegmina, N. 138819-AB [USNM (LW 98) 41236]. Paratypes: fragments of bodies and legs (sex unknown); 5 specimens: N. 27088 \& 27321 [USNM (AP LS 95) 41088], N. 50450-AB [USNM (DS 96) 41220], N. 30175-AB [USNM (LS 97) 41225], N. 27184 [USNM (AP LS 95) 41088], N. 137817 [USNM (LW 98) 41236].

DESCRIPTION. Fore and middle legs with uniformly darkish femora, and their tibiae somewhat shorter than femora; hind legs with slight oblique stripes on femora and without distinct spots on tibiae (Fig. 13). Cerci long and thin, but shorter than hind femur (see Measurements).

MEASUREMENTS (in mm). Length of body 13; length of fore femur 4.5-5; length of fore tibia 3.9-4.1; length of middle femur 4.3-4.8; length of middle tibia 3.8-4; length of hind femur 12; length of cercus 9 .

\section{Eozacla problematica Gorochov, sp.n.} Figs 14-15.

MATERIAL. Holotype: incomplete imprint of body with indistinct venation and without hind part of wings as well as without hind legs and abdomen (sex unknown), N. 75765 [USNM 40193 (Anvil Points)]. Paratypes: partly indistinct imprint of female body with ovipositor and without hind legs, N. 25422-AB [USNM (AP LS 95) 41088]; 5 fragments of bodies (sex unknown): N. 115178 [USNM 40910 (Anvil Points - Pribyl)], N. 28934 [USNM (AP LS 96) 41222], N. 30658-A [USNM (AP LS 95) 41075], N. 115163 [USNM 40910 (Anvil Points - Pribyl)], N. 25763 [USNM (AP LS 95) 41088].

DESCRIPTION. Similar to E. arachnomorpha sp.n., but fore and middle legs with distinctly spotted femora, and lengths of their femora and tibiae practically equal (Fig. 14). Ovipositor with apex as in Fig. 15 .

MEASUREMENTS (in $\mathrm{mm}$ ). Length of body 12-14; length of pronotum 1.8-2; length of fore femur 3.8-4; length of fore tibia 3.9-4.1; length of middle femur $4-4.2$; length of middle tibia 4.2-4.4; length of ovipositor 8.3.

COMPARISON. Distinctions from E. arachnomorpha sp.n. are listed in the description of E. problematica sp.n.
Eozacla sp.

MATERIAL. Imprint of hind part of body of male with hind wings, hind legs, and cerci only, N. 75785 [USNM 40193 (Anvil Points)].

NOTE. The absence of fore and middle legs don't give any possibility to compare this imprint with the both previous species. The rather large size of hind tibia (its length $11 \mathrm{~mm}$; hind femora incompletely visible) may indicate belonging of this imprint to E. arachnomorpha sp.n. (having slightly larger size) as well as to E. problematica sp.n. (having relatively longer tibiae), but the uniformly darkish coloration of hind legs may indicate its belonging to the latter species (with unknown hind legs) or a third species.

Genus Eotrella Gorochov, gen.n.

Type species: E. mira sp.n.

DIAGNOSIS. Medium-sized cricket with comparatively short legs and long hind wings. Fore tarsi with short basitarsus and very short second segment probably provided with widened pulvillae (Fig. 16); hind femora slightly wider than in Eozacla gen.n.; hind tibia distinctly shorter than hind femur and with sparse small denticles between larger and articulated spines (Fig. 19). Male tegmina with rather wide dorsal part, almost straight oblique veins, strongly curved chords, comparatively short diagonal vein, large mirror with 2 angularly curved dividing crossveins, well developed long cell along hind part of mirror, and possibly long apical area (Fig. 17); lateral part of these tegmina rather wide, with numerous and almost transverse branches of $\mathrm{Sc}$, and with rather narrow areas between Sc, R, and M (Fig. 18).

INCLUDED SPECIES. Type species only.

COMPARISON. This genus is very different from all known representatives of Phalangopsinae and related subfamilies in the structure of tarsi which is rather similar to Podoscirtinae. However it differs from the latter subfamily in the presence of 2 dividing crossveins in mirror of male tegmina. The latter character is an important feature of Phalangopsinae and related subfamilies (Phaloriinae, Pteroplistinae, Cacoplistinae), but it is a primitive condition of mirror usual for Baissogryllidae (extinct Mesozoic family ancestral for Gryllidae) and Early Cretaceous subfamilies of possible Gryllidae. In this connection, the belonging of the new genus to Phalangopsinae is problematical, as it may be a representative of a new subfamily related to Phalangopsinae, but with the adaptations for life on leaves of trees as in Podoscirtinae. From recent Phalangopsinae, Phaloriinae, Pteroplistinae, Cacoplistinae, and Gryllomiminae (a single recent subfamily not related to Phalangopsinae and having 2 dividing crossveins in mirror), the new genus differs in the shortened fore tarsi similar to those of Podoscirtinae; from all the Early Cretaceous groups of Grylloidea, in the presence of characteristic (for recent Gryllidae) loop from 1A and 2A in basal part of male tegmen; and from Paleogene genera belonging or related to Phalangopsinae (see Note after the diagnosis of Eozacla), in the distinctly shorter basitarsus of fore leg and/ or strongly angularly curved dividing crossveins in mirror.

\section{Eotrella mira Gorochov, sp.n. Figs 16-19.}

MATERIAL. Holotype: imprint of body of male with long wings, distinct tegminal venation, parts of legs, and indistinct outlines of head, pronotum, and abdomen, N. $85405 \& 85344$ [USNM 40189 (Old Mountain)].

DESCRIPTION. Tegmina with transverse stridulatory vein, 5 oblique veins, and almost round mirror (Fig. 17); proximal branches of tegminal Sc slightly S-shaped (Fig. 18). 
Fore tarsi with basitarsus distinctly shorter than third segment (Fig. 16); spines of hind tibiae as in Fig. 19. Coloration indistinct.

MEASUREMENTS (in mm). Length of pronotum 1.5 or 2.5 (?); length of visible part of tegmen 10 (possible length of tegmen 14-16); length of fore tibia 3 ; length of fore tarsus 1.7 ; length of hind femur 6.5 .
Trigonidiinae incertae sedis

MATERIAL. Imprint of bodies of small crickets with indistinct venation and structure of some other parts of body: 1 female, N. 86898 [USNM 40189 (Old Mountain)]; 1 male, N. 52909 [USNM Site 1 (DS 99) K, 41679]; 2 specimens (sex unknown): N. 50454 [USNM (DS 96) 41220], N. 31068 [USNM (LS 98) P, 41235].

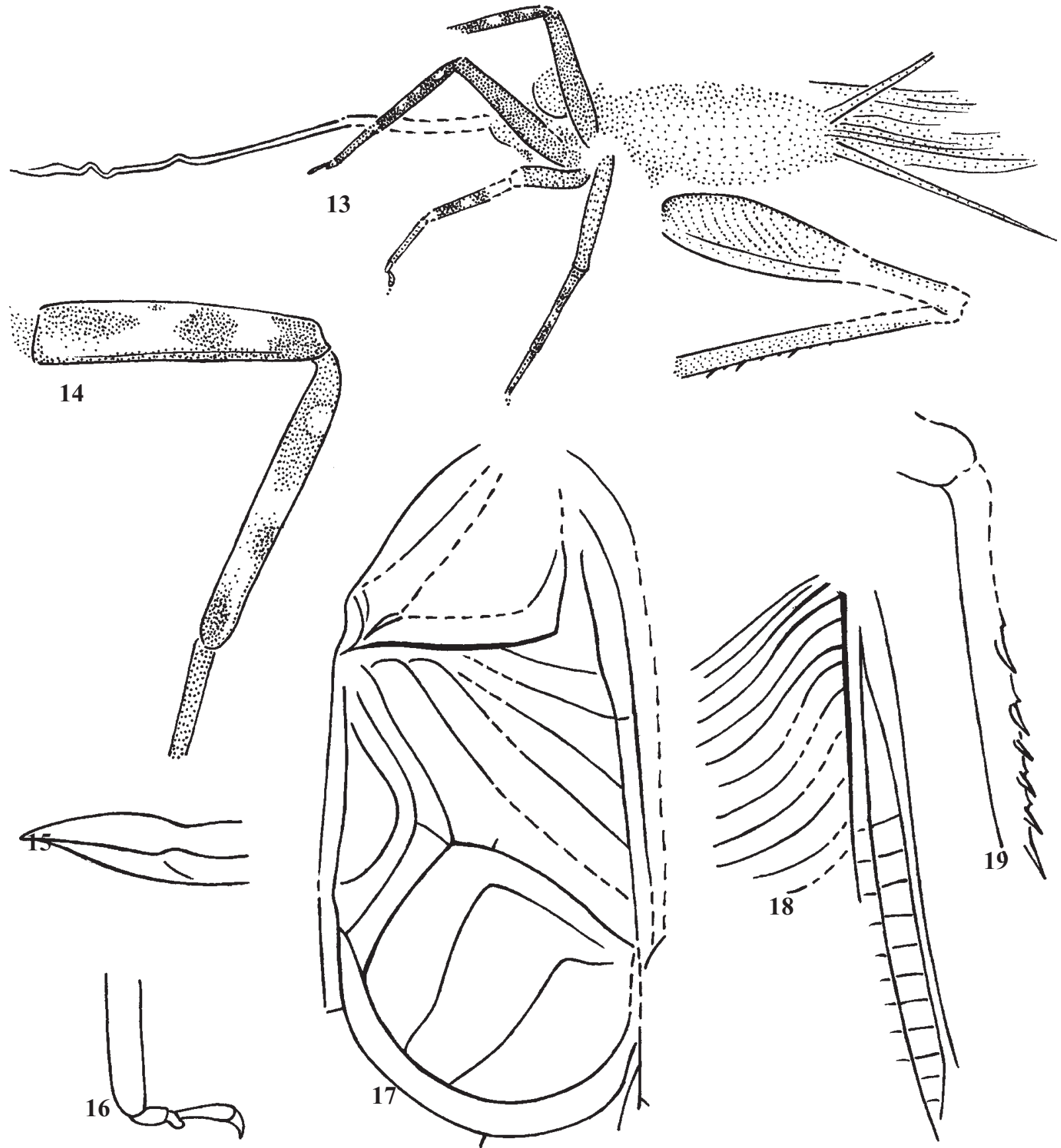

Figs 13-19. Gryllidae: 13 - Eozacla arachnomorpha sp.n. (holotype No. 138819, male); 14-15 - Eozacla problematica sp.n. (14 holotype No. 75765; 15 — paratype No. 25422); 16-19 — Eotrella mira sp.n. (holotype No. 85405 \& 85344, male); 13 — part of body from below; 14 - fore leg from side; 15 - apex of ovipositor from side; 16 - fore tarsus from side; 17 -18 — dorsal (17) and lateral (18) parts of right tegmen without distal areas; 19 - proximal half of hind tibia from side.

Рис. 13-19. Gryllidae: 13 - Eozacla arachnomorpha sp.n. (голотип № 138819, самец); 14-15 — Eozacla problematica sp.n. (14 голотип № 75765; 15 — паратип № 25422); 16-19 - Eotrella mira sp.n. (голотип № 85405 \& 85344, самец); 13 — часть тела, снизу; 14 - передняя нога, сбоку; 15 - вершина яйцеклада, сбоку; 16 - передняя лапка сбоку; $17-18$ - дорсальная (17) и латеральная (18) части правого надкрылья без дистальных участков; 19 - проксимальная половина задней голени, сбоку. 
NOTE. The female (Fig. 23) undoubtedly belongs to this subfamily as the structure of its hind tibiae and especially shape of its ovipositor are very characteristic of this subfamily. However the other parts of body are insufficiently preserved for including of this specimen in one of known genera or for description of a new formal genus. The other abovementioned specimens are included in Trigonidiinae mainly on the base of general outlines of body and its parts.

\section{Possible Nemobiinae}

MATERIAL. Imprints of bodies of small crickets with insufficiently preserved legs: 1 male with partly visible tegminal venation, $\mathrm{N}$ 57057 [USNM 41142, Denson 2001, Site \# 4]; 1 specimen with indistinct venation (sex unclear), N. 25348 [USNM (AP LS 95) 41088].
NOTE. The structure of spines of hind tibiae in these specimens is unknown or indistinct, but in Nemobiinae, this structure is important for determination of this subfamily. The belonging to Nemobiinae is supposed by the small size, shape of body, and traces of tegminal venation in one of these imprints (Fig. 22). The latter specimen lacks hind wings, but in the second specimen, these wings are long.

\section{Possible Pentacentrinae}

MATERIAL. Imprints of bodies of slender crickets with indistinct venation and long wings (sex unknown); 4 specimens: $\mathrm{N}$. 29672 [USNM (LS 97) 41225], N. 31259 [USNM (LS 99) K, 41678], N. 55166 [USNM (2001) (Denson site 4) 41142], N. 28626 [USNM (LS 99) K, 41678].

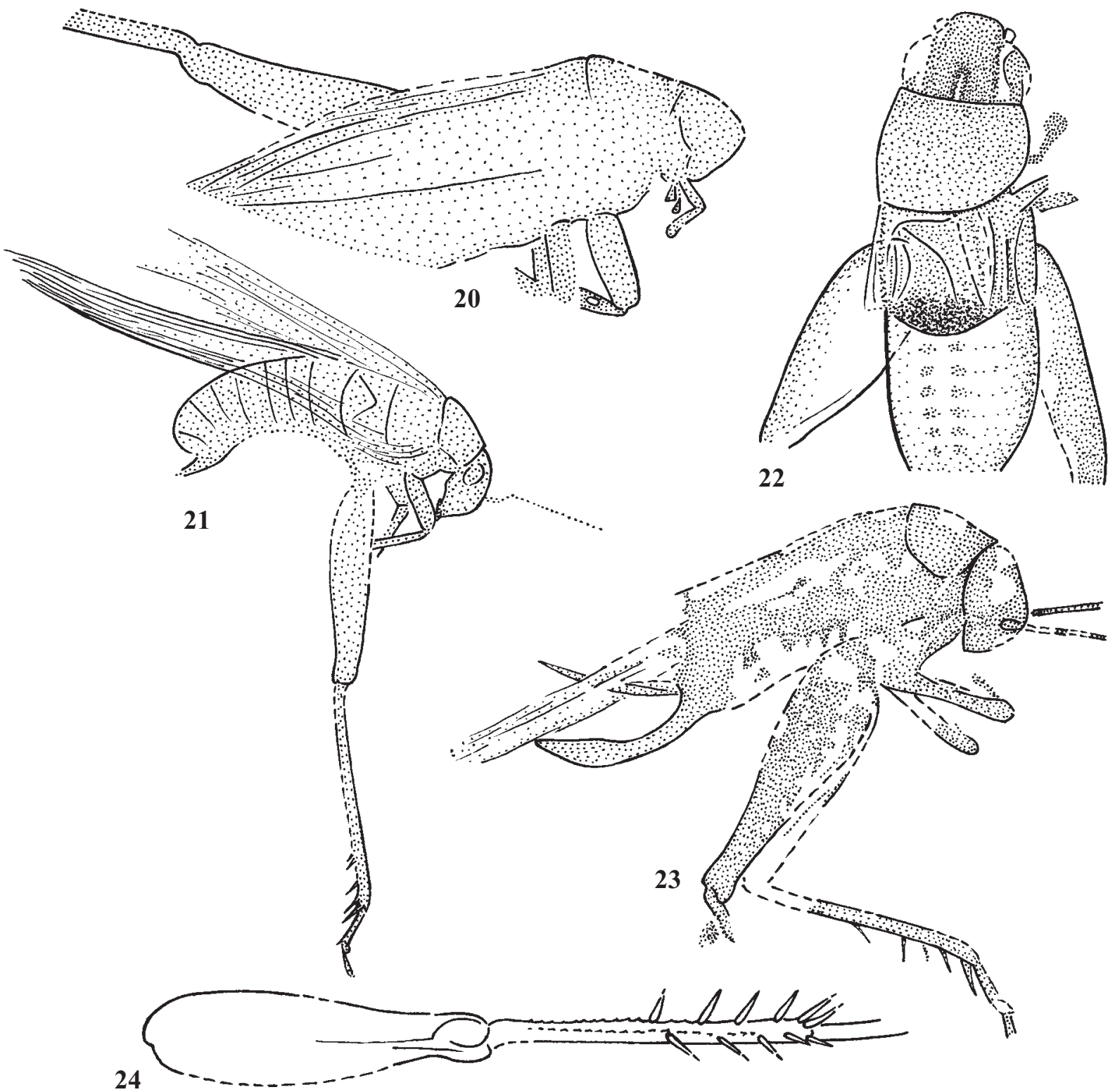

Figs 20-24. Gryllidae: 20 - possibly Podoscirtinae; 21 - possibly Pentacentrinae; 22 - possibly Nemobiinae (male); 23 Trigonidiinae gen. et sp. (female); 24 — possibly Eneopterinae; 20-23 — body or its part from (21-21, 23 — from side, 22 - from above); 24 - hind leg from side and partly above.

Рис. 20-24. Gryllidae: 20 - возможно, Podoscirtinae; 21 - возможно, Pentacentrinae; 22 - возможно, Nemobiinae (самец); 23 Trigonidiinae gen. et sp. (самка); 24 - возможно, Eneopterinae; 20-23 - тело или его часть; 20-21, 23 - сбоку; 22 - сверху; 24 задняя нога, сбоку и частично сверху. 
NOTE. These fossils are similar in general outlines to Pentacentrinae or Aphonoidini (Indo-Malayan and AustraloOceanian tribe of Podoscirtinae including small and slender crickets), but tarsi in one of these fossils are with rather long basitarsus (Fig. 21). The latter character is characteristic for Pentacentrinae, but not for Podoscirtinae. The specimen pictured may be a female, as it is provided with short indistinct stripe (possible base of ovipositor) at its abdominal apex. These specimens are insufficiently preserved for including them in any recent genus or in a new formal genus.

\section{Possible Podoscirtinae}

MATERIAL. Imprint of body without distal parts of legs and wings, with indistinct venation, and without hind part of abdomen (sex unknown), N. 27243 [USNM (AP LS 95) 41088].

NOTE. This imprint (Fig. 20) has not characters necessary for exact determination of this subfamily. It is determined as a possible representative of Podoscirtinae on the base of its general outlines (angular head in profile, shortened fore femora, medium-sized body). However this imprint may belong also to the genus Eotrella gen.n. having general appearance more or less similar to that of Podoscirtini (see Note after Diagnosis of Eotrella gen.n. above).

\section{Possible Eneopterinae}

MATERIAL. Imprints of bodies of males and females of rather large crickets with indistinct venation and imprints of isolated hind legs; 16 specimens: N. IKAO 745 \& IKAO 447 [USNM 40193 (Anvil Points)], N. 57226 [USNM 41142, Denson 2001, Site \# 4], N. 85583 [USNM (OM 95) 41086], N. 87679 [USNM 40189 (OM 95) 41221], N. 25657 [USNM 40189 (AP LS 95) 41088], N. 29076 [USNM (LS 99) K, 41678], N. IKAO 734 (77906) [USNM 40193 (Anvil Points)], N. 75763 [USNM 40193 (Anvil Points)], N. 25535 [USNM (AP LS 95) 41088], N. $75739 \& 75738$ [USNM], N 106186-AB [USNM (MT 98) 41234], specimen with only number of locality [USNM 40193 (Anvil Points)], N. 25423-AB [USNM (AP LS 95) 41088], N. 55273-AB [USNM (2001) (Denson Site 4) 41142], N. 157083 [USNM].

NOTE. The including of these specimens in Eneopterinae is very problematical. It is based on the following characters: more or less large and globular head, presence of rather long articulated spines and numerous small denticles on hind tibiae (Fig. 24), more or less long basitarsi, and comparatively large size. These specimens belong to more than 1 species, as there are some variations in the length of legs (fore and middle femora $2.5-3 \mathrm{~mm}$; fore and middle tibiae $2-2.5 \mathrm{~mm}$; hind tibiae $7-10 \mathrm{~mm}$ ) and coloration (hind femora are from striped almost as in Pronemobius to uniformly darkish as in Eogryllus gen.n.). The hind wings are long. It is impossible to exclude that enigmatic Pronemobius induratus Scudder, 1890 from the same locality may belong to this group of crickets judging by its size (Scudder, 1890).

\section{Gryllidae incertae sedis}

MATERIAL. Imprints of bodies or their fragments with rather indistinct outlines; about 300 specimens.

\section{Infraorder Tettigoniidea}

This infraorder includes 3 or 4 superfamilies: Hagloidea (Triassic-recent), Tettigonioidea (Cretaceous-recent), Stenopelmatoidea (Cretaceous-recent), and possibly Phasmomimoidea (Jurassic). Belonging of a new genus described below to Tettigonioidea or Phasmomimoidea is less probable, as this genus lacks widened tarsal pulvillae characteristic for these superfamilies (excepting maybe their most primitive representatives). Belonging of this genus to Hagloidea or Stenopelmatoidea is more probable, as majority of their representatives are with the narrow tarsi lacking widened tarsal pulvillae. More exact determination is now impossible, as the venation of wings in this genus is indistinct.

\section{Genus Tettoraptor Gorochov, gen.n.}

Type species: T. maculatus $\mathbf{s p .} \mathbf{n}$.

DIAGNOSIS. Body medium-sized for this infraorder. Head hypognathous, rather high, with rounded rostrum and well developed eyes (Fig. 25). Fore and probably middle legs raptorial (femora strong, widened in base; femora and tibiae with numerous denticles and small spines along lower edges); their tibiae slightly shorter than femora, and fore ones provided with distinct open tympanum; their tarsi with 4 segments and without widened pulvillae (Fig. 27); hind legs not very large, but distinctly larger than fore legs. Wings long. Coloration spotted (Figs 26-27) and with almost feather-like ornament on outer side of hind femora (Fig. 26).

INCLUDED SPECIES. Type species only.

COMPARISON. Judging by its raptorial legs, the genus includes specialized predators. The characteristically widened base of these femora well separates this genus from all known Tettigoniidea (including predaceous representatives). The absence of widened tarsal pulvillae shows that Tettoraptor gen.n. cannot be confidently included in the families Tettigoniidae and Phasmomimidae. The presence of tympana shows that this genus also cannot be put in the families Stenopelmatidae and Rhaphidophoridae. So, it may be a relict of Hagloidea (more probably, of the youngest family Prophalangopsidae), a representative of the family Haglotettigoniidae (primitive group of Tettigonioidea, most ancient representatives of which might have the narrow tarsi), or a specialized member of the family Anostostomatidae (Stenopelmatoidea).

\section{Tettoraptor maculatus Gorochov, sp.n.}

Figs 25-27.

MATERIAL. Holotype: imprint of isolated fore leg, N. 51386 [USNM Site 4 (DS 98) 41617]. Paratype: imprint of body with less distinct outlines, with indistinct venation, without most part of pronotum and hind legs, without distal part of wings, and without abdomen, N. 75270 [USNM 40193 (Anvil Points)].

DESCRIPTION. Fore femora narrowing near apex (Figs 25,27 ), with thin and not long articulated spines along lower edge; fore tibiae comparatively narrow, with slightly curved distal part and not long articulated spurs at apex; tarsi distinctly shorter than tibiae; lengths of their segments almost equal (each of two distal segments slightly shorter than second one which hardly shorter than basitarsus). Middle legs probably similar to fore ones. Coloration of fore and possibly middle femora light with darkish spots; coloration of fore tibiae and tarsi darkish with 3 light bands ( 2 on tibia and 1 on basitarsus) (Fig. 25); coloration of basal part of hind femora as in Fig. 26.

MEASUREMENTS (in mm). Height of head 6.4; length of fore femur $6.8-7.2$; length of fore tibia $6-6.3$; length of middle femur $\sim 6$; length of middle tibia $\sim 5.5$; length of hind wing without distal part 22 .

\section{Suborder Caelifera Infraorder Acrididea Superfamily Tetrigoidea Family Tetrigidae}

The fossils described below undoubtedly belong to this family, but it is impossible now to establish for them more exact systematic position. Moreover these specimens are included in the almost formal genus Eotetrix gen.n., described here for Paleogene representatives of Tetrigidae having the characters listed below. 
Genus Eotetrix Gorochov, gen.n.

Type species: E. unicornis sp.n.

DIAGNOSIS. Head typical of Tetrigidae; rostrum more or less rounded in profile, without angular projection; eyes rounded, not very large; antennal cavities situated near lower edges of eyes (Figs 28-29). Pronotum also typical of this family, with long hind process (covering most part of hind wings) and shorter frontal one (almost hook-like in shape) (Figs 28-29). Fore and possibly middle legs with 2 longitudinal keels on femora and 2 tarsal segments (Fig. 32); hind legs with widened femora (having characteristic oblique relief on outer surface), thin tibiae (provided with numerous small denticles on upper side and rather short apical spurs), and 3 tarsal segments (Fig. 31); hind basitarsus longer than both distal segments together and with traces of origin from 3 ancestral segments on ventral side (Fig. 31). Tegmina very short, lateral, and evidently with not very distinct venation (Fig. 30); hind wings long, with comparatively long distal part exposed behind hind pronotal process (Fig. 28). Cerci very short; ovipositor probably similar to that of recent Tetrigidae (Fig. 33).

INCLUDED SPECIES. Type species only.

COMPARISON. The genus is almost formal taxon (see the paragraph about Tetrigidae) created here for Paleogene representatives with the more or less straight upper edge of pronotum in profile and with large hook-like anterior pronotal projection. From the Late Eocene genus Succinotettix Piton, 1938 as well as from the Miocene representatives of Antillotettix Perez-Gelabert, 2003 and Baeotettix Heads, 2009, the new genus differs in the distinctly larger anterior pronotal projection. From the Cretaceous genera described by Sharov [1968], Eotetrix gen.n. differs in the smaller tegmina with the rather reduced venation (as in the recent representatives).

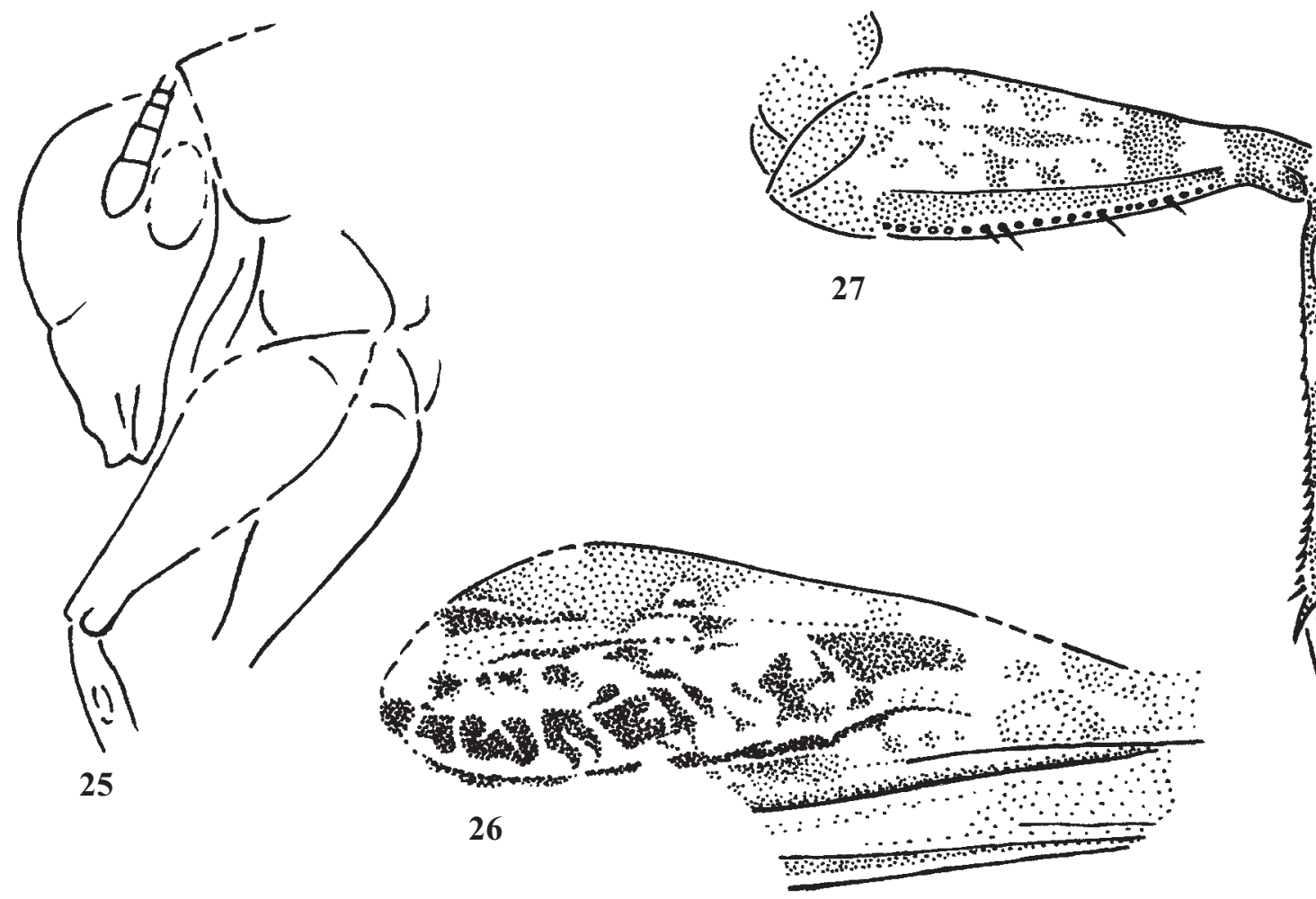

Eotetrix unicornis Gorochov, sp.n.

Figs 28-33.

MATERIAL. Holotype: imprint of almost complete body with not very distinct outlines of its central part and abdominal apex (sex unknown), N. $86908 \& 80698$ [USNM 40189 (Old Mountain)]. Paratypes: imprints of incomplete bodies with indistinct outlines of some parts, fragments of bodies, and isolated legs; 20 specimens: $\mathrm{N}$. 57885 [USNM 41142, Denson 2001 Site \# 2], N. 75301 [USNM 40193 (Anvil Points)], N. 75324-5 [USNM 40193 (Anvil Points)], N. 106242-A [USNM (MT 98) 41234], N. 51196 [USNM (DS 97) P, 41223], N. 87677 [USNM (OM 96) 41221], N. 54451 [USNM Site \# 4 (DS 00) 41822], N. 50466 [USNM (DS 96) 41220], N. 78720 [USNM (Anvil Points) 41141], N. 26224 [USNM (AP LS 95) 41088], N. 26986 [USNM (AP LS 95) 41088], N. 87667 [USNM (OM 96) 41221], N. 55646 [USNM 41142, Denson 2001, Site \# 5], N. 26216-AB [USNM (AP LS 95) 41088], N. 18689 [USNM (KS 97) 41226], N. 147092-AB [USNM (SAV 94) 40913], N. 75302 [USNM 40193 (Anvil Points)], N. 25721 [USNM (AP LS 95) 41088], N. 26130 [USNM (AL LS 95) 41088], N. 193 [USNM (AP KS 95) 41076].

DESCRIPTION. Coloration of body and its parts (excepting hind wings) more or less uniformly dark. Frontal hook-like process of pronotum not long and slightly curved downwards; its apex acute and situated almost near rostral apex. Tegmen with hardly notched lower edge; hind wings more than twice as long as hind femur. Hind tibia only insignificantly shorter than hind femur.

MEASUREMENTS (in mm). Length of pronotum 12 13; length of tegmen 3.1-3.2; length of hind femur 6-7; length of hind tibiae 5-6; length of preserved part of ovipositor 2; length of female body 14-16; length of body with wings in holotype 15.5 .

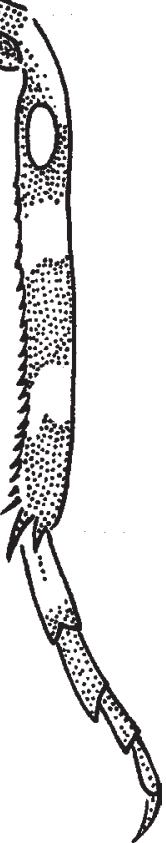

Figs 25-27. Tettoraptor maculatus sp.n. (family unknown): 25-26 — paratype No. 75270; 27, holotype No. 51586; 25 - fore part of body; 26 - proximal part of hind femur; 27 - fore leg; $25-27$ - from side.

Рис. 25-27. Tettoraptor maculatus sp.n. (семейство неизвестно): 25-26 — паратип № 75270; 27 — голотип № 51586; 25 передняя часть тела, 26 - проксимальная часть заднего бедра; 27 - передняя нога; 25-27 - сбоку. 


\section{Superfamily Eumastacoidea Family Eumastacidae}

The classification of the superfamily Eumastacoidea is problematical, because the different authors divide it into different number of families. A very disunited classification with several families is presented now in the Internet catalogue [Eades et al, 2012]. It is incomparable with the classification of Ensifera from the same catalogue in relation to the age of higher taxa and value of differences between them. In this connection, here I tentatively include all groups of the true Eumastacoidea, winged representatives of which lack $\mathrm{MP}+\mathrm{CuA} 1$ veins in tegmina (Fig. 34) and have a single MA branch in hind wings, in the same family Eumastacidae (apterous Proscopiidae may be another family of Eumastacoidea, but it seems more probable that Proscopiidae belong to the superfamily Acridoidea, as Proscopiidae, Acrididae, and some other related groups are characterized by the similar structure of abdominal stigma which is well distinguished from that of Eumastacidae [Gorochov, 1995b]). The specimens described below are very similar to representatives of Eumastacidae in the general appearance and tegminal venation. However their differences from recent genera are unclear, and their including in one of these genera cannot be substantiated, as for elaboration of generic system of these insects, we must study their genitalia which are not preserved in these imprints. It is a reason that we describe for them (as well as for many previous fossils) a new almost formal genus.

\section{Genus Eoerianthus Gorochov, gen.n.}

Type species: E. eocaenicus sp.n.

DIAGNOSIS. Body rather long, slender. Head rather high, in profile with almost rounded rostrum and slightly oblique facial part; eyes very large, almost vertical (Fig. 35). Pronotum comparatively small, with straight upper edge and short hind projection of disc (Fig. 35). Legs long and thin, but hind femora with slightly widened basal part; apex of each of these femora with small and angulate upper projection (or 2 projections?) (Figs 35-36); hind tibiae with numerous dense and moderately long spines (Figs 35-36); hind tarsi with denticles on upper surface of basitarsus. Wings long, extending distinctly behind apici of hind femora; tegmen narrow, with short secondary C, long Sc lacking distinct branches, distal branching of R and MA, single RA ending near tegminal apex, 3 visible branches of RS, 2 branches of MA, rather wide area between distal halves of $\mathrm{CuA}$ and $\mathrm{CuP}$.

INCLUDED SPECIES. Type species and possibly Tyrbula multispinosa Scudder, 1890 (USA, Wyoming; Middle Eocene).

COMPARISON. This almost formal taxon now cannot be well distinguished from recent Eumastacidae, but the distinctly distal position of both base of RS stock and base of MA branches is maybe a primitive condition characteristic also for the most ancient genera ascribed to Eumastacidae: Archaeomastax Sharov, 1968 (Upper Jurassic of Kazakhstan) and Promastax Handlirsch, 1910 (Oligocene of Canada). Kevan \& Wighton [1981] proposed the special family Promastacidae for this genus and for Promastacoides described from Paleocene of Canada in the same paper; however the latter genus is probably a representative of Susumanioidea (Phasmatoptera) in reality [Gorochov, 1988, 2000], and systematic position of Promastax is insufficiently clear (because its secondary $\mathrm{C}$ in tegmen is much longer than in more ancient Eumastacidae, and proximal half of its tegmen is unknown). From both these genera, the new genus differs in the following tegminal charac-

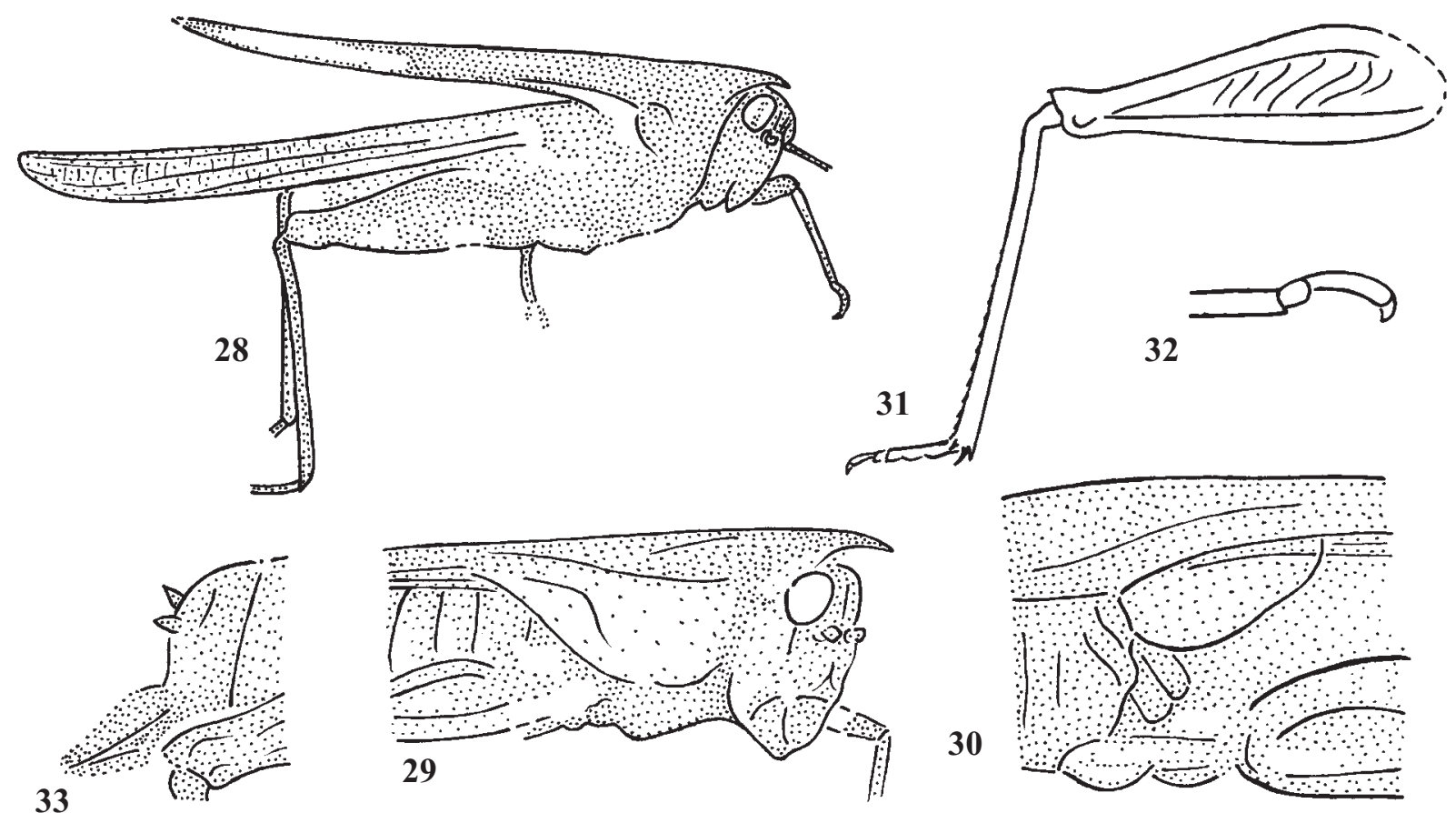

Figs 28-33. Eotetrix unicornis sp.n. (Tetrigidae): 28 — body from side (holotype No. 86908); 29 — fore half of body from side (paratype No. 57885); 30 - middle part of body from side (paratype No. 75301); 31 — hind leg from side (paratype No. 75324-5); 32 — fore tarsus from side (holotype); 33 - apex of abdomen and of hind femur from side (paratype No. 106242, female).

Рис. 28-33. Eotetrix unicornis sp.n. (Tetrigidae): 28 - тело сбоку (голотип № 86908); 29 - передняя половина тела, сбоку (паратип № 57885); 30 — средняя часть тела, сбоку (паратип № 75301); 31 — задняя нога, сбоку (паратип № 75324-5); 32 — передняя лапка сбоку (голотип); 33 - вершины брюшка и заднего бедра, сбоку (паратип № 106242, самка). 
ters: secondary C significantly shorter, Sc slightly longer, and distal half of area between $\mathrm{CuA}$ and $\mathrm{CuP}$ distinctly wider.

\section{Eoerianthus eocaenicus Gorochov, sp.n.}

Figs 34-36.

MATERIAL. Holotype: imprint of almost complete body without antennae, tarsi and abdominal apex, N. $86916 \& 86927$ [USNM 40189 (Old Mountain)]. Paratypes: imprints of incomplete bodies and isolated body parts; 27 specimens: N. 77131 [USNM 40193 (Anvil Points)], N. 85516 \& 85593 [USNM (OM 95) 41086], N. 28372-AB [USNM (LS 98) 41235], N. 50476 [USNM (DS 96) 41220], N. 29869-AB [USNM (LS 99) P, 41678], N. 75277 \& 75278 [USNM 40193 (Anvil Points)], N. 81698 \& 86918 [USNM 40189 (Old Mountain)], N. 55307 [USNM 2001 (Denson Site 4) 41142], N. 85340-AB [USNM 40189 (Old Mountain)], N. 75264 [USNM 40193 (Anvil Points)], N. 87687 [USNM (OM 96) 41221], N. 77143 [USNM 40193 (Anvil Points)], N. 87689-AB (2 specimens on the same stone) [USNM (OM 96) 41221], N. 75304 \& 75305 [USNM 40193 (Anvil Points)], N. 60698 or 86909 (?) [USNM 40189 (Old Mountain)], N. 75323 [USNM 40193 (Anvil Points)], N. 75283 [USNM 40193 (Anvil Points)], N. 50457 [USNM (DS 96) 41220], N. 86922 [USNM 40189 (Old Mountain)], N. 27864 [USNM (AP LS 96) 41222], N. 27186 [USNM (AP LS 95) 41088], N. 652-AB [USNM (KS 97) 41226], N. 27855 [USNM (AP LS 96) 41222], N. 28773-AB [USNM (LS 99) K, 41678], N. 50484 [USNM (DS 96) 41220], N. 26973 [USNM (AP LS 95) 41088].

DESCRIPTION. Coloration of body more or less darkish, but wings transparent with darkish venation. Height of head (from upper edge of eyes to apex of mouthparts) and length of fore femur almost equal (Fig. 35); hind femur and tibia also equal in length; hind tibial apical spurs rather short, not longer than distal spines of this tibia (Fig. 36). Tegmina with distinctly convex costal edge in distal half; hind visible branch of tegminal RS slightly shorter than fore branch of tegminal MA and hardly longer than hind branch of the latter vein.

MEASUREMENTS (in mm). Length of body 18-22; length of pronotum 2-2.4; length of tegmen 17-24; length of fore femur 3.6-3.8; length of hind femur 11-16; length of hind tibia $11-16$

COMPARISON. The differences between this species and E.? multispinosa comb.n. are not very clear, as the latter species was described for isolated hind wings and a hind leg from the same Eocene locality (Green River, Wyoming) as well as for a hind femur from another locality (Florissant, Colorado) dating as Miocene one by its author [Scudder, 1890] and Zeuner [1944]. Hind wings of the new species are unknown, but hind leg of E.? multispinosa from Green River is larger than in E. eocaenicus. The femur from Florissant may belong to another genus, possibly to the Florissant genus Tyrbula Scudder which was put by its author [Scudder, 1890] and Zeuner [1944] in the family Acrididae. The latter author in this paper indicated one of the syntypes from Green River (hind wings) as "holotype" of E.? multispinosa, and I think that this action must be treated as a designation of lectotype.

\section{Brief discussion}

The most interesting feature of the fauna of Orthoptera in these deposits is significant domination of crickets, especially Gryllinae and Mogoplistidae. The latter groups are very numerous, and the abundance of Gryllini (not characteristic for dry and forest landscapes) allows one to suppose that this locality in Eocene was presented by wide meadows around large water reservoir (or reservoirs). This hypothesis is supported by the presence of Gryllotalpidae characteristic for such landscape in recent time. The recent Mogoplistidae lacks hind wings and is rather rare in such landscapes, but in these deposits, this group is presented only by forms with long hind wings. It is possible that in Eocene, such primitive extinct genera of Mogoplistidae might be usual in meadows near water (as Gryllini). The presence of possible Nemobiinae and Trigo-

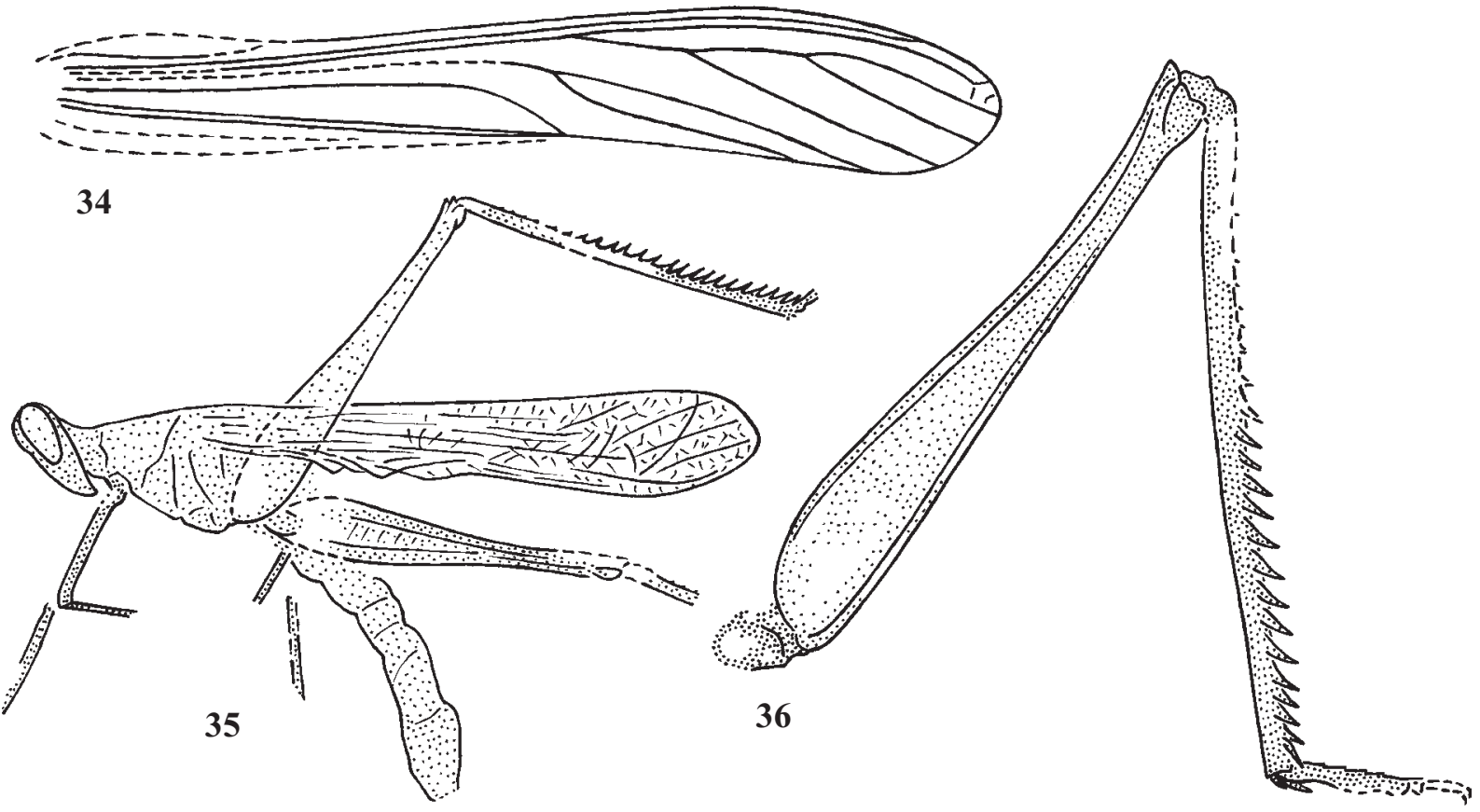

Figs 34-36. Eoerianthus eocaenicus sp.n. (Eumastacidae): 34 - reconstruction of tegmen (paratype No. 77131); 35 - body from side (holotype No. 86916 \& 86927); 36 - hind leg from side (paratype No. 85516 \& 85593).

Рис. 34-36. Eoerianthus eocaenicus sp.n. (Eumastacidae): 34 — реконструкция надкрылья (паратип № 77131 ); 35 — тело, сбоку (голотип № 86916 \& 86927); 36 — задняя нога, сбоку (паратип № 85516 \& 85593). 
nidiinae also supports this hypothesis. Moreover, if majority of the recent Eneopterinae is not very usual in such landscapes, some its genera are characteristic for the stations almost lacking forest, but situated near it. For primitive Eocene Eneopterinae, life in meadows might be more usual than now. Pentacentrinae, Podoscirtinae, and Phalangopsinae are inhabitants of forests, as they live on trees. For Pentacentrinae and Podoscirtinae, it is possible to suppose life on bushes or separated trees out of forest, because they are connected with leaves, but for Phalangopsinae and many of their relatives living on tree trunks and under tree bark, life out of forest is little probable. In this connection, we must admit the presence of forests situated not near large water reservoir (place of insect deposition), but separated from it by the rather wide meadows. Comparative abundance of Tetrigidae and Eumastacidae in this fauna doesn't contradict the above-mentioned hypothesis. The recent Tetrigidae is usual in forests as well as in meadows near water. The Eumastacidae is more characteristic now for tropical forests, but in Eocene (in connection with absence of Acridoidea), this group might be a partial predecessor of Acridoidea in open landscapes near water (for example, as inhabitants of small bushes in meadows).

Another important feature of this fossil fauna is almost complete absence of the infraorder Tettigoniidea (excepting enigmatic Tettoraptor). No true Hagloidea, Tettigonioidea, and Stenopelmatoidea (the first group is one of dominants in Mesozoic deposits of Eurasia; the second group is one of recent dominants in majority of regions with more or less warm climate; the third one is usually presented now by the forest inhabitants). It is interesting, but in much less rich Paleocene deposits of different continents as well as in the Late Eocene Baltic amber and in many deposits formed after Early Oligocene, the Tettigonioidea and Stenopelmatoidea are present. A most similar fossil fauna of Orthoptera is found only in England [Gorochov, unpublished data]; it is Early Oligocene deposits in Isle of Wight (Insect Limestone). This fauna is also with domination of Gryllinae and with rather numerous Gryllotalpidae. Such forest inhabitants as Phalangopsinae or related groups are also rare. However one of orthopteran dominants in this fauna is the true Acrididae which possibly replaced Eumastacidae in the opened meadow landscapes near water. The infraorder Tettigoniidea is presented by only one rare species. Possibly in the Early and Middle Paleogene (up to Early Oligocene as minimum), the Tettigoniidea was presented mainly by forest inhabitants. It penetrated meadows and grasslands somewhat later. It is possible that in Paleocene, such wide meadows near large water reservoirs were less developed, and forest insects might get in water deposits more often.

ACKNOWLEDGEMENTS. The authors thank all their colleagues collecting this rich paleoentomological material and giving a possibility for the first coauthor to study it during his short visit to the National Museum of Natural History (Washington) supported by a grant of the Smithsonian Institution in 2005. Work of the first coauthor is also supported by the Presidium of Russian Academy of Sciences (Program "Biosphere origin and evolution of geo-biological systems") and Russian Foundation for Basic Research (project \# 10-04-00682).

\section{References}

Capra F. 1977. Sulla Gryllotalpa fossile del Monte Bolca // Bollettino del Museo Civico di Storia Naturale di Verona. Vol.4. P.423-427.
Cockerell T.D.A. 1921. LVII. - Fossil Arthropods in the British Museum. - VI. Oligocene Insects from Gurnet Bay, Isle of Wight // Annals and Magazine of Natural History (Series 9). Vol.7. No.42. P.453-480.

Eades D.C., Otte D., Cigliano M.M., Braun H. 2012. Orthoptera Species File Online. http://osf2.orthoptera.org/HomePage.aspx Gorochov A.V. 1983. [A contribution to the study of crickets from the tribe Gryllini (Orthoptera, Gryllidae)] // Entomologicheskoe Obozrenie. Vol.62. No.2. P.314-330 [in Russian].

Gorochov A.V. 1984. [A contribution to the taxonomy of modern Grylloidea (Orthoptera) with a description of new taxa] // Zoologicheskiy Zhurnal. Vol.63. No.11. P.1641-1651 [in Russian].

Gorochov A.V. 1988. [Classification of fossil orthopterans from the superfamily Phasmomimoidea (Orthoptera) with description of new taxa]// Trudy Zoologicheskogo Instituta AN SSSR. Vol.178. P.32-44 [in Russian].

Gorochov A.V. 1992. [New and little-known fossil Grylloidea (Orthoptera) from Eurasia] // Paleontologicheskiy Zhurnal. No.2. P. $96-102$ [in Russian].

Gorochov A.V. 1995a. [System and evolution of the suborder Ensifera (Orthoptera)] // Trudy Zoologicheskogo Instituta AN SSSR. Vol.260. No.1, 2. P.1-224, 1-213 [in Russian].

Gorochov A.V. 1995b. [Contribution to the system and evolution of the order Orthoptera] // Zoologicheskiy Zhurnal. Vol.74. No.10. P.39-45 [in Russian].

Gorochov A.V. 2000. [Phasmomimidae: are they Orthoptera or Phasmatoptera?] // Paleontologicheskiy Zhurnal. No.3. P.67-72 [in Russian].

Gorochov A.V. 2010. [New and little known orthopteroid insects (Polyneoptera) from Fossil Resins. Communication 4] // Paleontologicheskiy Zhurnal. No.6. P.56-71 [in Russian].

Kevan D. K. McE., Wighton D. C. 1981. Paleocene orthopteroids from south-central Alberta, Canada // Canadian Journal of Earth Sciences. Vol.18. No.12. P.1824-1837.

Martins-Neto R.G. 1995. Complementos ao Estudo sobre os Ensifera (Insecta, Orthopteroida) da Formação Santana, Cretáceo Inferior do Nordeste do Brazil // Revista Brasileira de Entomologia. Vol.39. No.2. P.321-345.

Martins-Neto R.G. 1997. Cratotetraspinus nov. nom., novo nome para Tetraspinus Martins-Neto 1995 (no. preoc.) // Revista Universidade Guarulhos (Série Geociências). Vol.2. No.6.P.105.

Otte D. 1994. Orthoptera species file, 1. Crickets (Grylloidea) // Philadelphia, Orthopterists' Society and Academy of Natural Sciences of Philadelphia. $120 \mathrm{p}$.

Perrichot V, Neraudeau D., Azar D., Menier J.-J., Nel A. 2002. A new genus and species of fossil mole cricket in the Lower Cretaceous amber of Charente-Maritime, SW France (Insecta: Orthoptera: Gryllotalpidae) // Cretaceous Research. Vol.23. P.307-314

Scudder S.H. 1878. Art. XXXII. - The fossil insects of the Green River shales // Bulletin of the United States Geological Survey. Vol.4. No.2. P.516-544.

Scudder S.H. 1890. The Tertiary Insects of North America // Report of the United States Geological Survey of the territories, 13. Washington, Government Printing Office. 734 p., 28 pl.

Secretan S. 1975. Un orthoptère fossile du Monte Bolca // Studi e ricerche sui giacimenti terziari di Bolca. II. Miscellanea paleontologica. Verona, Museo Civico di Storia Naturale di Verona. P.427-430.

Smith M.E., Carroll A.R., Singer B.S. 2008. Synoptic reconstruction of a major ancient lake system: Eocene Green River Formation, Western United States // Geological Society of America Bulletin. Vol.120. No.1/2. P.54-84.

Sharov A.G. 1968. [Phylogeny of orthopteroid insects] // Trudy Paleontologicheskogo Instituta AN SSSR. Vol.118. P.1-216 [in Russian].

Zeuner F.E. 1944. XXXVIII. - The Fossil Acrididae (Orth. Salt.). - Part IV. Acrididae incertae sedis and Addendum to Catantopinae // Annals and Magazine of Natural History. Vol.11. No.11. P.359-383. 